\title{
BASED SUSTAINABLE INDIVIDUAL FOREST MANAGEMENT \\ LOCAL FUNCTIONS IN THE DESA LUBUK BERINGIN \\ BATHIN III ULU BUNGO DISTRICT
}

\author{
Norsidi \\ Program Studi Pendidikan Geografi \\ Fakultas Ilmu Pendidikan dan Pengetahuan Sosial (IPPS) \\ IKIP-PGRI Pontianak \\ Email :habibisukma1991@gmail.com
}

\begin{abstract}
Forest Resources Lubuk Beringin Village is an important resource area for people who have various economic, social and environmental functions. The people of Lubuk Beringin Village have their own local wisdom in managing forest resources. This study aims to find out the ways of society in local wisdom-based forest management in the future in the future Lubuk Beringin Village, Bungo Ulu District, Bungo Regency. The method in this study is qualitative research which aims to explore deep social situations. Data collection is done through observation, and in-depth interviews. In-depth interviews were conducted with purposive sampling and snowballing sampling techniques for key informants of the Village Head (Rio), Customary Figures, Religious Leaders and Community Leaders. The results of this study indicate that the people of the Village of Lubuk Beringin, Bathin III Ulu District, Bungo Regency have been guarding and conserving forests based on their local wisdom for decades, firmly upholding the traditions, which were obtained from their ancestors, by observing the procedures for managing land use processes, land clearing, and cultivation and plantation processes, utilization of forest resources and patterns of forest management along with the imposition of sanctions in accordance with customary agreements for communities that have been proven to have violated or deliberately damaged forest resources.
\end{abstract}

Keywords: Customary Forest, Local Wisdom

\section{INTRODUCTION}

Forest is an area that is overgrown with thick trees and other plants. Forest is a guarantee for food security or what is known as food insecurity (Imam, 2006). Forests are one of the important resources for Indonesia which is located in the wet tropics because these forests have strategic ecological values at the global level (Mardiatmoko, 2008). As in Law No.41 of 1999 concerning forestry, it is an ecosystem unit in the form of a stretch of land containing biological natural resources dominated by trees in the fellowship of their natural environment, which cannot be separated from one another. Lubuk Beringin village which is part of its territory is a protected forest area in the long hill of Rantau Bayur which extends 
extensively from Dusun Sungai Telang SubDistrict of Bathin III Ulu to Dusun Batu Kerbau Pelepat District, Bungo Regency with an area of 13,529.40 Ha. The people of Lubuk Beringin Village are very dependent on the existence of forests. Forest ecosystems store and have abundant natural resource potential in the form of wood and non-timber to be taken advantage of by the community through cultivation of agricultural crops in the surrounding forest land.

In addition to economic benefits, the forests in Lubuk Beringin Village have environmental functions that play a role in various things such as water source providers, oxygen producers, influence and control rainfall and help stabilize the world's climate by storing huge amounts of carbon to prevent the occurrence of global warming. Forests are an inseparable part of people's lives. Forest natural resources as a determinant of the survival of indigenous peoples who are customary rights of customary property whose management must be based on traditional rules. A characteristic of local wisdom that characterizes groups of forest edge farmers community there is a close relationship between the process of survival with forest use (Imam, 2006).

The people of Lubuk Beringin Village have their own rules in managing forest resources. The management and utilization of the community divides forest management into three functions, namely the prohibited forest, is a customary forest whose entire contents cannot be utilized, sesap (rubber and shrubs) and non-timber utilization forest areas. For forest edge farmers, local wisdom is an absolute thing that contains social values and is used as a source of thought and behavioral guidelines to preserve the ecosystem of forest resources (Imam, 2006). The Lubuk Beringin Village community has a conservation concept for its own environment since 1997 by holding on to the village conservation agreement (KKD) as an effort to maintain the forest. This agreement is a long process built by the community to maintain the sustainability of the remaining forest ecosystem functions in the village area, especially for the Rantau Bayur Bukit Panjang Protected Forest area.

The community agreed that the harvesting of timber and non-timber forest products as well as clearing agricultural land in the Village Forest Area outside the Protected Forest area must be approved by the village (after being approved by the Pemdes, LKMD, Customary Figures, and Religious Leaders). For people who violate, they will be summoned and tried to be given sanctions in accordance with the mistakes (violations) committed according to the applicable Customary Law that have been agreed upon in Lubuk Beringin Village. The customary forest area of Lubuk Beringin 
Village is very important in this study because it has the value of local wisdom which is still maintained today. Local Wisdom is knowledge, understanding and habits that direct human life in people's lives in ecological communities (Amri Fauzul et al., 2013).

According to the formulation issued by the Ministry of Social Affairs (2006), local wisdom is as a means of life and knowledge as well as various life strategies in the form of activities carried out by local communities in answering various problems in meeting their needs. Other opinions expressed by (Zulkarnain \& Febrimansyah, 2008). The initiation of forest area management carried out by the community by starting the formation of customary forest areas in a participatory manner and then being developed into a village forest scheme (HD) was quite successful in touching the community in terms of economic value. The Lubuk Beringin Village Forest was the first village determined by the Indonesian Minister of Forestry through Decree No. 109 / Menhut-II / 2009 concerning the stipulation of the working area of village forest in the protected forest area of the hill with a length of $\pm 2,356$ hectares.

\section{RESEARCH METHODS}

This research was conducted in Lubuk Beringin Village, Bungin Ulu
District, Bungo Regency with qualitative research methods, to explore deep social situations. Qualitative research is "conducted through an intense and prolonged contact with a" field "or life situation. These situations are typically "normal", normal, replica of the everyday life of individuals, groups, societies and organizations "(Miles \& Huberman, 1994). This qualitative research aims to understand all-all phenomena-social phenomena in society from the perspective of the participant's perspective. Participants are people who are invited to interview, observed, are asked to provide data, opinions, thoughts and perceptions (Sukmadinata, 2006). Data collection is done through observation, and in-depth interviews. In-depth interviews were conducted with a purposive sampling technique using key informants including the Village Head (Rio), Customary Figures, Religious Leaders and Community Leaders. Each informant interviewed was also asked about residents who could be used as informants then proceeded to use snowball sampling, to be able to provide further information development to the level of saturation or already collected data that reached the level of adequacy.

\section{RESULT AND DISCUSSION}

The community of Lubuk Beringin Village, Bungo District Ulu District, Bungo District, 
since dozens of years ago, has always maintained and cared for sustainable customary forests that are still being carried out. Management of community forest resources based on local wisdom in the form of knowledge and regulation of customary law. Local wisdom is dynamic, flexible, open, and always adjusts to its era (Wagiran, 2011). The values taught to society are known as teachings of value (waardenleer). Customary values are inseparable from the life of the community which is an element of unity like the proverb "like a chicken, allied like lemongrass, Besikek like a banana, batut tub like sugarcane". Communities are aware that forests have important functions and meanings as places to earn a living, providers of water resources, conservation areas, and other functions.

The form of community forest management in the Lubuk Beringin Village by applying customary rules to all levels of society which if there are those who are proven to violate and do logging or damage to the forest is subject to sanctions and fines for the community in accordance with customary provisions. The Indigenous Forest Area of Lubuk Beringin Village has become part of local wisdom based on knowledge, understanding and habits believed by the community. The customary forest of the Lubuk Beringin village in the distribution of the area is intended for agricultural activities, the area designated for hunting and prohibited forest areas.

These areas have been properly regulated in accordance with customary provisions and used in accordance with their functions, for example the agricultural area of the Lubuk Beringin village must use the area for agricultural activities and also the hunting area. For prohibited forest areas, the community of Lubuk Beringin Village is not permitted to do logging or damage because the forest area is a conservation area, as a provider of springs and sloping areas to prevent landslides during the rainy season. These rules are made so that the forest resources found in Lubuk Beringin Village such as wood, rattan, manau, resin and medicinal plants are still available to all those who need and are sustainable.

The community is aware of the attitudes, actions and behaviors that are friendly to the forest and the environment will not appreciate the results of the creator of nature entrusted to humans. Forests also provide various types of medicines and food. Nature conservation functions, one of which is to meet these needs, namely recreational areas in the open, for example National Parks (Siombo, 2011). The proof of the community has a caring attitude reflected in the existence of traditional ritual ceremonies as well as requests for permits when opening the forest for gardening and farming purposes. The 
following results from the utilization of forest natural resources in the form of wood and non-timber by the people of Lubuk
Beringin Village to fulfill various daily needs can be seen in table 1 below:

Table 1. Timber and Non Timber Forest Products

\begin{tabular}{|l|l|l|}
\hline No & Forest products & Utilization \\
\hline 1 & Wood & $\begin{array}{l}\text { Wood, used for raw materials for building houses, } \\
\text { mosques and facilities for building village needs. }\end{array}$ \\
\hline \multirow{5}{*}{2} & \multirow{2}{*}{ Non Wood } & $\begin{array}{l}\text { Rattan, to make crafts such as chairs, tie fences } \\
\text { and sell rattan products. }\end{array}$ \\
\cline { 3 - 4 } & $\begin{array}{l}\text { Bamboo, for the walls of a buffalo or cow cage } \\
\text { house, and make a bridge. }\end{array}$ \\
\cline { 3 - 4 } & $\begin{array}{l}\text { Sago, the leaves are used to make the roof of the } \\
\text { house, the contents of the sago tree are made into } \\
\text { a cake making cakes and processed into food. }\end{array}$ \\
\cline { 3 - 4 } & $\begin{array}{l}\text { Honey, for personal consumption, for medicine, } \\
\text { and honey harvested on the market. }\end{array}$ \\
\hline
\end{tabular}

Source: Primary Data Analysis, 2016

Most of the land in Lubuk Beringin Village is customary land which is subject to or controlled by the head of the local indigenous community. Every citizen who wants to manage and utilize a piece of land that is in the area of customary rights must be on the knowledge and permission of the head of an indigenous community called Rio (Village Head). Rio is a customary title given by customary institutions through traditional leaders / traditional leaders to someone who is considered capable of leading a village whose position is the same as the village head with a mechanism directly chosen by the Lubuk Beringin Village Community.

The people of Lubuk Beringin Village have their own concept to regulate land use planning that is adjusted to the characteristics of natural resources. Land use by the people of Lubuk Beringin Village is only designated as residential land and agricultural land which is regulated by the tribe (Batin). It is this mind that regulates the land use procedure if every citizen opens a new land, both for rice, farming and settlement activities. The people of Lubuk Beringin Village have a special land that is intended for the "Behumo" field of rice fields, namely the "Belah Lasah / Sesap" land which is between the upstream areas of the Alai River, Taklim River, and Sungai Pauh. The process of forest clearing begins with a farewell / permit to survey the location of the traditional leaders "berajo nature, rantau bejenang, kampung betuo, the land with the grandmother mamak" (Forests opened must be known by the chief in traditional meetings) and then perform traditional rituals. The land that will be cultivated is certainly not opened and done as he pleases, 
but it has been regulated by customary cultural values, then invites one of the traditional leaders in the community to examine the land. Arriving in the forest, the traditional leader led a prayer to God Almighty so that the land clearing went smoothly. After that, the process of land clearing began to work together.

Behumo is a term for rice fields planted once a year for one season while the Lasah / Sesap Thicket is an area that used to be a forest area which was then cleared for land but abandoned but it is not clear who opened it, then determined through village consensus for the land processed and used as seasonal agricultural areas which may be managed jointly by the local village community. The area designated for behumo by the spiritual tribe should not be extended to plantation activities or as agricultural land. If the behumo area does not produce a source of staple food, it will become a suction area, then it will be replaced by a lustful one. Although Belukor can no longer produce basic food sources for the community, there are still many leaves of fruit trees and various plants that are beneficial to them such as durian, duku, setubung, tenggeris trees and clear trees whose leaves are used as roofs, besides it is also wood containing which can be used for tuba fish and various types of rattan including manau and jernang.
The turn around in the use of forest resources by the people of Lubuk Beringin Village from the jungle into fields and then sipping, belukor and benuaron, finally returning to the jungle, is a traditional cultural wisdom inherited from generation to generation which is still maintained so as not to affect forest destruction. Until now, the forest area is maintained and its authenticity is maintained because the community thinks this area is an area that cannot be damaged. Almost all Lubuk Beringin villagers source their livelihood as agricultural cultivation by conducting farming and gardening activities from generation to generation. The cultivation system is still traditional in nature, which has been passed down from generation to generation so that it becomes the local knowledge of farmers in carrying out cultivation activities in agriculture and plantations. The people of Lubuk Beringin village, almost all of them own gardens to grow crops with the development of a variety of crop patterns.

This plantation system still continues today and is known as the rubber agroforestry system. Besides being the main source of income, rubber plants also provide income for farmers and maintain the diversity of flora and fauna that live in them. In addition, old rubber gardens have a high level of biodiversity that is no less important than natural forests. In old rubber gardens there 
are woody plants and shrubs and others so that they are not monoculture. Rubber agroforestry areas can also be a place or habitat for various types of biodiversity as well as enough potential to accommodate the growth of forest plant species. Rubber plants began to be maintained and developed into plantation commodities since the Dutch era. According to the informant, the initial spread of rubber seedlings occurred during the Dutch occupation by distributing rubber seedlings to the people of Rantau Pandan and until now it can still be found that the old rubber trees that were first planted were called the Land Bouw rubber tree.

Ecologically, community rubber agroforestry in Lubuk Beringin Village functions as a protector and catchment of water systems and conservation of natural resources while economically proven to be able to contribute to increasing family income while conserving forest resources. the existence of this water is very important in the quantity, quality and certain time that can be expected to ensure the sustainability of the sustainability of people's lives and environment in a sustainable manner (Norsidi, 2016). Whereas socioculturally, rubber gardens also play a role in maintaining local culture as a form of local wisdom. The rubber plantations developed by Masyarajkat are also used as protected gardens and have characteristics that may not be duplicated by the region or elsewhere.

Traditional traditions and local values applied by the community are still very effective and effective in realizing forest protection. Their traditions and values also encourage local wisdom-based forest management by running a shifting cultivation system. The concept of local wisdom carried out by the community in forest management is known as the type of land that is young and old-fashioned. The emergence of a young and old sip is beginning with the process of intentionally opening up the farming area made by the community by clearing the forest. The succession process takes place after the fields have been left formed in a young, soddy land. Through the succession process, diversity of vegetation or forest grows naturally in young and old sips land. At first glance, it is seen as young and old as a sip which is formed after the field is left and left to look like land.

Different from old sips or shrubs that are formed after the fields have been left for more than 3 years, there are more varied types of plants. Old sesap is often used by the community as a place for harvesting fruit from trees and also for building materials. In old sips, there are also different types of medicinal plants that are different from young ones. The old suction land is considered by the community to be quite 
important as a place to take the main food plants for the community. In this old suction area there are also rubber trees that are planted with ages ranging from 5-6 years which are considered the best age for tapping rubber sap.

The Lubuk Beringin Village community built a customary agreement to conserve the forested village area based on the aspirations of the community towards the norms and rules set out in the form of regulations carried out by the village institutions as a form to oversee the conservation of protected areas and KSNP. Following is the agreement as a real role of the community of Lubuk Beringin Village, Bungin Ulu District, Bungo Regency based on customary norms and law:

1. The community agreed not to extract timber and non-timber forest products and clear forests for agricultural land within the Protected Forest and Kerinci Seblat National Parks.

2. The community agrees to take wood and non-timber forest products and clear land for agriculture in the Village Forest Area outside the Protected Forest and KSNP areas, with the permission of the village (after being approved by the Pemdes, LKMD, Customary Figures and Religious Figures) ,.

3. The community agreed not to process agricultural lands continuously (behumo) on sloping / steep lands, river banks, and upstream rivers so that landslides, floods / erosion, or irrigated rice fields would not occur.

4. If there is a violation of the agreement, the community agrees to call and hear the Offender before the Adat trial, in order to be given sanctions according to the mistake (violation) committed according to Customary Law applicable in Lubuk Beringin village. If it still violates, the community agrees to report it to the relevant authorities (BTNKS, Forestry Police, Police, etc.) for law enforcement.

5. The lands of the people who are already included in the Protected Forest area are allowed to be managed / cultivated, and the land becomes the deadline for cultivation.

6. Each decides and decides on village regulations (new village regulations, fines, sanctions and other regulations) must be decided in official village meetings (there are invitations and officially announced) involving Pemdes, LKMD Customary Figures, Religious Leaders and community members. Deliberation results must be announced / affixed and come into force after the stipulated date of stipulation.

Local wisdom-based forest management in people's lives can prove to improve the economy of the community, as 
well as maintain the function of the ecology of the forest and not over-exploit natural forest resources. Local wisdom is not only influenced by ecological and economic factors, but is more determined by the dynamics of community development to achieve adaptation and survival (Imam, 2006). In addition, local wisdom that is owned can grow and develop attitudes and attitudes to always maintain a harmonious relationship between God, humans and nature (the forest environment). The community of Lubuk Beringin Village, Bathin III Ulu District, Bungo Regency also built a customary agreement to conserve the forested area of his village based on the aspirations of the community towards the norms and rules set out in the form of village institutions which they oversee the preservation of protected areas and KSNP . Moreover, this forest is above the ulayat of tribal people and ulayat, its management and utilization are under the supervision of ninik mamak kaum or ninik mamak Suku.

\section{CONCLUSION}

Conclusively the results of this study that the people of Lubuk Beringin Village have been protecting and conserving forests for decades based on their local wisdom firmly upholding the traditions, which were obtained from their ancestors, by looking at the management procedures in the process of land use, land clearing and cultivation plantations, utilization of forest resources and patterns of forest management along with sanctions in accordance with customary agreements for communities that have been proven to violate or damage forest resources.

\section{REFERENCE}

Amri Fauzul dkk. (2013). Kearifan Lokal Lubuk Larangan Sebagai Upaya Pelestarian Sumberdaya Perairan di Desa Pangkalan Indarung Kabupaten Kuantan Singingi. Jurnal Pusat Penelitian Lingkungan Hidup, Tidak diterbitkan.

Imam, S. (2006). Eksistensi Kearifan Lokal Pada Petani Tepian Hutan Dalam Memelihara Kelestarian Ekosistem Sumber Daya Hutan. Jurnal Wawasan Vol. 11, 11-20.

Mardiatmoko, G. (2008). Konsep revitalisasi pembangunan hutan rakyat penghasil damar untuk mencapai pengelolaan hutan berkelanjutan. Jurnal Agroforest Vol. III (2), 119-123.

McMillan, J. H., \& Schumacher, S. (2010). Research in Education (Evidence Based Inquiry). New Jersey: Pearson Education Inc.

Norsidi. (2016). Pelestarian Daerah Aliran Sungai Berbasis Kearifan Lokal Lubuk Larangan Desa Lubuk Beringin Kecamatan Bathin III Ulu Kabupaten Bungo. Jurnal Pendidikan Sosial Vol. 3, 274-285. 
Sukmadinata. (2006). Metode Penelitian Pendidikan. Bandung: Remaja Rosdakarya.

Wagiran. (2011). Pengembangan Model Pendidikan Kearifan Lokal Dalam Mendukung Visi Pembangunan Provinsi Daerah Istimewa Yogyakarta 2020 (Tahun Kedua).
Jurnal Penelitian dan Pengembangan Vol. III, Nomor 3, 85100.

Zulkarnain, A., \& Febrimansyah. (2008). Kearifan Lokal dan Pemanfaatan dan Pelestarian Sumberdaya Pesisir. Jurnal Agribisnis Kerakyatan, 69-85. 